\title{
Alkol Tüketiminin Osmanlı Kamusal Hayatında Yarattı̆̆ı Sorunlar: İkinci Meşrutiyet Dönemi Ve Sonrasından Örnekler
}

\author{
Fatih Arslan*
}

(ORCID: 0000-0002-3265-9462)

\author{
Makale Gönderim Tarihi \\ 04.05.2021
}

Makale Kabul Tarihi

19.09.2021

\section{Atıf Bilgisi/Reference Information}

Chicago: Arslan, F., "Alkol Tüketiminin Osmanlı Kamusal Hayatında Yarattığı Sorunlar: İkinci Meşrutiyet Dönemi Ve Sonrasından Örnekler", VakanüvisUluslararası Tarih Araştırmaları Dergisi, 6/2 (2021): 478-497.

APA: Arslan, F. (2021). Alkol Tüketiminin Osmanlı Kamusal Hayatında Yarattığı Sorunlar: İkinci Meşrutiyet Dönemi Ve Sonrasından Örnekler. VakanüvisUluslararası Tarih Araştırmaları Dergisi, 6 (2) , 478-497.

Öz

Kullanıldığında insanlara bir süreliğine sarhoşluk hali veren alkol, tarihsel süreç içerisinde pek çok medeniyet tarafından bilinmiş ve tüketilmiştir. Bilinçsiz ve kontrol dışı kullanıldığında çeşitli problemlere neden olan alkol, II. Meşrutiyet Dönemi ve Mütareke yıllarında Osmanlı Devleti sınırları içerisinde de bazı sosyo-ekonomik sıkıntılara sebebiyet vermiştir. Bu sıkıntılar kamusal hayata da sirayet etmiş ve devletin çeşitli kurumlarında görev yapan memurlar içki yüzünden bazı asayiş ihlallerine neden olmuştur. Devletin okulundaki öğrenciden ordusundaki askere, karakolundaki polisten bahriyesindeki nefere kadar pek çok kamu çalışanı alkolün tesiriyle olaylara karışmış ve işledikleri suçlardan ötürü cezalandırılmıştır. Bu makalede II. Meşrutiyet Dönemi ve Mütareke yıllarına ait birtakım örneklerle, Osmanlı devletinde görev yapan memurların tükettiği alkolün etkisiyle birlikte çıkardığı

\footnotetext{
* Yüksek Lisans Öğrencisi, Sakarya Üniversitesi Fen Edebiyat Fakültesi Tarih Bölümü, Türkiye, f.arslan22044@gmail.com.

MA Student, Sakarya University Faculty of Arts and Sciences Department of History, Turkey.
}

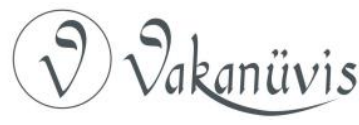


asayiş olayları anlatılarak bunun sonucunda karşılaştıkları sorunlar ile çektikleri cezalara değinilmiştir. Ayrıca çalışmanın esas gayesi, II. Meşrutiyet Dönemi'nde ve sonrasında içkinin sebep olduğu asayiş olaylarını belirtip bu olayları da bizzat devlet memurlarının çıkardığı hususuna dikkat çekmek amacıyla kaleme alınmıştır.

Anahtar Kelimeler: Alkol, Asayiş, Memur, Suç, Ceza.

\section{Problems Caused by Alcohol Consumption in the Ottoman Public Life: Samples from the Second Constitutional Period and Afterwards}

\section{Abstract}

Alcohol, which gives people a state of intoxication for a while when used, has been known and consumed by many civilizations in the historical process. Alcohol, which causes various problems when used unconsciously and out of control, II. During the Second Constitutional Period and the Armistice years, it caused some socio-economic problems within the borders of the Ottoman Empire. These problems have also spread to public life, and civil servants working in various institutions of the state have caused some violations of public order because of alcohol. Many public employees, from a student at a state school to a soldier in the army, from the police in the police station to the soldier in the navy, were involved in the events under the influence of alcohol and were punished for their crimes. In this article II. With some examples from the Constitutional Monarchy Period and the Armistice years, the public order incidents caused by the effects of the alcohol consumed by the civil servants in the Ottoman state were explained, and the problems they faced as a result and the punishments they suffered were mentioned. In addition, the main purpose of the study, II. It has been written in order to indicate the public order incidents caused by alcohol during and after the Constitutional Monarchy Period and to draw attention to the fact that these incidents were caused by the civil servants themselves.

Keywords: Alcohol, Public Order, Officer, Crime, Punishment.

\section{İçki ile İgili Bazı Kavramlar}

İçki, çok eski dönemlerden beri insanlar tarafından kullanılan ve içildiğinde insanlara geçici olarak sarhoşluk veren bir içecek olmakla birlikte bira, şarap, konyak, votka, viski gibi türleri de bulunmaktadır.

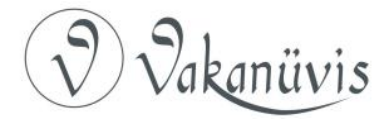


"iç̧inde alkol bulunan içecek" ${ }^{1}$ demek olan içki, pek çok toplum tarafından çeşitli amaçlarla kullanılmıştır. Kimi toplumlar keyif vermesi için kimileri sinirlerinin yatışması için kimileri de ilaç olarak tedavi amaçı kullanmışlardır². İcki ile alakalı olarak kullanılan pek çok kavram bulunmaktadır. Arapça'da kullanılan işret kelimesi "içki içme, içki kullanma" manasına gelmektedir ${ }^{3}$. Yine Arapça'da kullanılan mükeyyifat kelimesi ise "keyif veren, sarhoşluk getiren" anlamına gelmektedir ${ }^{4}$. Ve yine Arapça aslında uygun bir şekilde kullanılan kökü seker olan müskirat kelimesi de "sarhoşluk veren şeyler" anlamını karşılamaktadır ${ }^{5}$. Günümüzde kullanılan alkol kelimesi ise, kirpikleri boyarken kullanılmakta olan pudra biçimindeki toz manasına gelen elküûl'den gelmektedir 6 . Illaveten, hamr kelimesi de "üzümden yapılan şarap" anlamındadır”. İcki, İngilizce alcohol, Fransızca alcool, Almanca alkohol olarak ifade edilir. ${ }^{8}$ Alkolü karşılayan İspirto kelimesi de Latince bir kelime olup spiriitus kökünden gelmektedir. Spirit kelimesi Batı dillerinde alkol dâhil diğer birçok anlamda telaffuz edilir 9 .

\section{Alkolün Tarihteki Yeri ve Önemi}

İçkinin tarihsel gelişimine bakıldığında çok eski zamanlardan itibaren kullanılmış olduğu görülmektedir. İnsanlar, tabiatın kendisine sunduğu nimetlerden faydalanmasını bildiği zamanlardan itibaren bazı içki çeşitlerini üretmeyi becerebilmişlerdir ${ }^{10}$. İçkinin tarihini Hz. Âdem'e

1 "içki”, Büyük Larousse Sözlük ve Ansiklopedisi, Cilt: 11, s.5559.

2 Fatih Öncü, Kültegin Ögel, Duran Çakmak, "Alkol Kültürü-2: İçki Kültürü Ve Edebiyatta İçki" Bağımlılık Dergisi, Sayı 3, 2002, s.32.

${ }^{3}$ Ferit Devellioğlu, Osmanlıca-Türkçe Ansiklopedik Lûgat, Aydın Kitabevi, 24.Baskı, Ankara, 2007, s.466.

${ }^{4}$ Devellioğlu, Osmanlıca-Türkçe Ansiklopedik Lûgat, s.717.

${ }^{5}$ Şemseddin Sami, Kâmûs-ı Türkî, Çağrı Yayınları, İstanbul, 2012, s.1344

6 Serkan Erdal, Hasan Demirci, Pir Murat Sivri, " Meşrutiyet'ten Cumhuriyet'e Türkiye'de içki ile Mücadele ve Hilâl-i Ahdar Cemiyeti (1908-1927), Kitabevi Yayınları, İstanbul, 2019, s.1.

7 Nebi Bozkurt, "içki", Diyanet İslam Ansiklopedisi, Türkiye Diyanet Vakfı Yayınları, İstanbul, 2000, Cilt 21, s. 455.

${ }^{8}$ Erdal, Demirci, Sivri, “ Meşrutiyet'ten Cumhuriyet'e Türkiye'de Içki Ile Mücadele, s.2.

9 Özcan Köknel, "Alkol ve Madde Bağımlıı̆̆ı", Altın Kitaplar Yayınevi, İstanbul, 1998, s.22.

10 Kemal Sülker, Osmanlı'dan Günümüze İçki ve Toplum, Süreç Yayıncılık, Aralık, 1985, s.13.

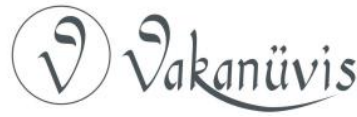


kadar götürenler bulunmaktadır ${ }^{11}$. Konuyla ilgili anlatılan bir diğer rivayet ise Tevrat'ın Tekvin 9/20-21. ayetlerinde bahsedilen ve içkinin $\mathrm{Hz}$. Nuh tarafından bulunduğu bahsidir ${ }^{12}$. Şark geleneğine göre de şarabı bulan kişinin İran Şahı Cem/ Cemşid olduğu söylenmektedir. ${ }^{13}$ Mısır'da da içki kullanıldığı bilinmektedir. Nitekim Hz. Yusuf'un zindanda rüya tabiri yaptığı iki kişiden biri şarap sakisiydi ${ }^{14}$. Yine eski medeniyetlerde şarap tanrıları bulunmaktaydı. Eski Yunan'da Dionysos, eski Roma'da Bacchus denilen şarap tanrıları vardı ve bunlar adına düzenlenen ayinlerde şarap fazlaca tüketilirdi ${ }^{15}$. Ortaçağ'da Avrupa'da şarap ve bira çokça tüketilirdi. Su içmek yerine bira içilmesi genel bir tercih ve hatta mecburiyet bile olabilirdi. Çünkü kullanılan suların temiz olmadığı ve bulaşıcı hastalıklara neden olduğu kanaati oldukça yaygınd $\imath^{16}$. Arap toplumlarına bakıldığında ise İslam öncesi dönemde içki kullanılmakla birlikte kumar ve fuhuş gibi kötü alışkanlıklar da mevcuttu. Şarapçılık, uğraştıkları ve ticaretini yaptıkları bir diğer sanayi kolunu oluşturmaktaydı ${ }^{17}$. Arap edebiyatında da içki kavramı oldukça geniş bir yer bulmuştur ve içki konusunu ihtiva eden şiirlere de "hamriyyat" denilmiştir. ${ }^{18}$. İslam'ın ve Kuran-ı Kerim'in yeryüzünde yayılması üzerine içki alışkanlığı birden bire değil, belirli aşamalar

11 Saîd b. Müseyyeb ve Yezîd b. Kâsid gibi kişiler $\mathrm{Hz}$ Âdem'in yasak meyveyi $\mathrm{Hz}$. Havva'nın verdiği içkinin tesiriyle yediğini söylemektedirler. İbnü'l- Arabî bu düşüncenin hükümsüz olduğunu ifade eder. Bozkurt, "içci", s.455.

12 Erdal, Demirci, Sivri, “ Meşrutiyet'ten Cumhuriyet'e Türkiye'de içki Ile Mücadele, s.5.

1315 gün boyunca yedikleri üzüm kaynatılınca tadının güzel olmadığı anlaşılmış zehir olduğu kanaati oluşmuştur. Baş ağrısından muzdarip bir cariye intihar etmek üzere onu zehir niyetine içtikten sonra faydası ve tadı görülmüştü. Bu yüzden şaraba Şâhdâru adı verildi. Kudret Emiroğlu, "Gündelik Hayatımızın Tarihi", 3. Baskı, Dost Yayınları, Ankara, 2002, s.355.

${ }^{14}$ Bozkurt," içki", s.455.

15 Erdal, Demirci, Sivri, " Meşrutiyet'ten Cumhuriyet'e Türkiye'de içki Ile Mücadele, s.6.

${ }^{16}$ Erdal İnce, "ikinci Meşrutiyet Döneminde Müskirat ve Müskirat Satan Yabancı Esnafa İzin Verilmesi, Tarih ve Günce Atatürk ve Türkiye Cumhuriyeti Tarihi Dergisi, II/5, 2019 Yaz, s.415.

17 Abdülkerim Özaydın, "İslam'dan Önce Araplarda Sosyal ve İtisadi Hayat", Diyanet islam Ansiklopedisi, Türkiye Diyanet Vakfı Yayınları, İstanbul, 1991, Cilt:3, s.322.

18 Ince, "Iikinci Meşrutiyet Döneminde Müskirat ve Müskirat Satan Yabancı Esnafa İzin Verilmesi, s.416.

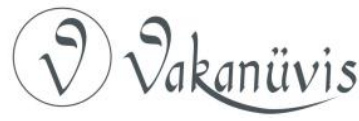


halinde bu alışkanlıklarının önüne geçebilmeleri amacıyla tedricen yasaklanmıştır ${ }^{19}$.

Eski Türklerde içki denildiğinde ise akla ilk olarak kımız gelmektedir. Kısrak sütünün ekşitilmesiyle birlikte elde edilen içeceğe kımız adı verilirdi ${ }^{20}$. Kımızın üretimi ise bir yayık içerisinde devamlı bir şekilde çalkalanması ile gerçekleşirdi ${ }^{21}$. İçerisindeki alkol miktarı \% 2 civarındadır ve insan damağında oluşturduğu tat ise ekşi ayranı anımsatmaktadır ${ }^{22}$. Ve yine kımızın insan sağlığına olan pek çok faydası da bilinmektedir. Bu bağlamda, içildiğinde insanlara cesaret veren, olumsuz düşünceleri yok eden, yaşlılık ve dermansızlık gibi pek çok rahatsızlı̆ın şifası olarak içilmiştir. Seyyahların ifadelerine bakıldığında Cengiz Han, zamanında kısrak sütünün çok olması nedeniyle kımız dışında bir şey içmedikleri ifade ediliyor ${ }^{23}$. Bozkurt, Türk içki Geleneği isimli eserinde, Eski Türklerin ant içme törenlerinde de içki tükettiği bilgisini vermektedir. Buna ek olarak yine Göktürklerde gerçekleştirilen şölenlerde de şarap sunulduğu bilgisi vardır. ${ }^{24}$ Halil İnalcık, HasBağçede 'Ayş u Tarab isimli eserinde K. Jetmar'a göre "en ince ayrıntılarına kadar düzenlenmiş içki âlemleri"nin hükümdarın şanını ve gücünü arttıran bir tür âyîn hükmünde olduğunu ifade etmektedir ${ }^{25}$.

Müslümanların içkiyle olması gereken ilişkileri, Kuran-ı Kerim'de konu ile ilgili ayetlerde ve $\mathrm{Hz}$. Peygamber'in hadislerinde açık bir şekilde belirtilmiştir. Kuran ve hadisler çoğu hususta olduğu gibi içki konusunda da insanlara rehberlik etmiştir. Bilindiği gibi İslam dini yayılmadan önce içki, Hicaz-Arap toplumunda fazlaca kullanılan bir

19 Yeter Öztürk, "XIX. Yüzyıl Arşiv Belgelerine Göre Osmanlı Devleti'nde İcki Yasakları" (Yayınlanmamış Yüksek Lisans Tezi), Ordu Üniversitesi Sosyal Bilimler Enstitüsü Tarih Anabilim Dalı, Ordu, 2017, s.11.

20 İlhami Durmuş, "Türk Kültür Çevresinde Kımız", Milli Folklor Dergisi, 2014, Yıl 26, Sayı 104, s.77.

${ }^{21}$ Ruslan Adil Akai Tegin, Zafer Gönülalan, "Bütün Yönleriyle Doğal Fermente Ürün, Kımı" , Manas Journal of Engineering, 2014, Sayı: 2 (1), s.26.

22 Çağatay Üstün," Eski Bir Türk İçeceği: Kımız (Koumıss)" Türklük Bilinci Araştırmaları (TÜBAR), 2009-Güz, s.248.

${ }^{23}$ Bahaeddin Ögel, Türk Kültür Tarihine Giriş IV, Kültür Bakanlığı, Ankara, 1991, s.175.

${ }^{24}$ Fuat Bozkurt, Türk içki Geleneği, Kapı Yayınları, İstanbul, Ağustos, 2006, s.24-25;

Erdal, Demirci, Sivri, “ Meşrutiyet'ten Cumhuriyet'e Türkiye'de içki ile Mücadele, s.8.

25 Halil İnalcık, Has-Bağçede 'Ayş u Tarab: Nedîmler, şâîler, Mutrîbler, 4. Baskı, İş Bankası Kültür Yayınları, İstanbul, Mart 2018, s.73.

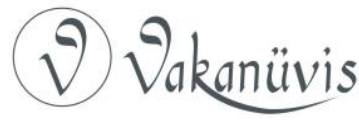


içecekti. Arap toplumlarındaki durum bu şekilde olduğundan İslam'ın insanları içkiden vazgeçirme yönteminde hem ikna edici hem de tedrici bir metot kullanılmış ve belli aşamalardan sonra açık ve net bir yasaklama getirilmiştir ${ }^{26}$. Nitekim Kuran'daki ayetler insanlara içkiyi terk etme konusunda yol göstermiştir ${ }^{27}$. Yine bu hususta $\mathrm{Hz}$. Peygamber'in hadisleri de mevcuttur ${ }^{28}$. Müslümanlara haram edilen içkinin yine tekrar kullanılması bazı cezaî müeyyideleri kendiyle birlikte getirmiştir. Yasağa uymayanlara dayak atmak, hapsetmek, baş, sakal ya da bıyık tıraş etmek ve maaştan kesinti gibi bazı cezalar verilmiştir ${ }^{29}$. İslam hukukuna göre içki içenler hadd-ı şirbi denilen suç kapsamında cezalandırııılardı. Bu suçu işleyenlerin 80 sopa dayakla ya da $\operatorname{tazir}^{30}$ ile cezalandırılmalarına hükmedilirdi ${ }^{31}$. Yine suçun cezasının tatbik edilmesi için bazı şartların sağlanması gerektiği gibi bazı durumlarda da bu ceza uygulanamayabilirdi ${ }^{32}$. İslam'daki içki yasağının günümüze bazı

${ }^{26}$ Mustafa Baktır, "İslam'da İçki", Diyanet islam Ansiklopedisi, Türkiye Diyanet Vakfı Yayınları, Cilt:21 İstanbul, 2000, s.458

27 İçki ile ilgili ayetler şunlardır: "Hurma ağaçlarının ve üzüm asmalarının ürünlerinden hem içki hem de güzel besinler elde edersiniz. Bunda da aklını kullanan bir topluluk için açık delil vardır." (Nahl 16/67); "Sana şarap ve kumar hakkında soru soruyorlar. De ki: ikisinde de büyük günah ve insanlar için bir takım faydalar vardır. Ancak her ikisinin de günahı faydasından daha büyüktür." (Bakara 2/219); "Ey iman edenler! Sarhoş iken ne söylediğinizi bilinceye kadar namaza yaklaşmayın... (Nisa 4/43); "Ey inananlar! Şarap, kumar, dikili taşlar, şans okları şeytanın işi birer pisliktir. Bunlardan kaçının ki kurtuluşa eresiniz. Şeytan, şarap ve kumar ile aranıza düşmanlık ve kin sokmak, sizi Allah'ı anmaktan ve namazdan alıkoymak ister. Artık vazgeçtiniz değil mi?" (Maide 5/90-91)

28 "Sarhoş eden her içki haramdır."; "Çoğu sarhoş eden (içki)nin azı da haramdır."; "(içki içen) onu içerken (gerçek) mümin olarak içmez."; "Allah (c.c.) içki içenin namazını kırk sabah kabul etmez."; "(Şurası) muhakkak (ki) Allah (c.c.) size haram ettiği şeylerde sizin için şifa yaratmamıştır." Abdülaziz Bayındır, "islam Açısından Sarhoş Edici İçkiler", İslam Medeniyeti Mecmuası, Cilt:4, Sayı:3, İstanbul, Haziran 1980, s.4.

${ }^{29}$ Cem Doğan, "Osmanlı Men'-i Müskirat Cemiyeti ve Men'-i Müskirat Kanunu" Uluslararası Sosyal Araştırmalar Dergisi, Cilt 6, Sayı 26, Bahar 2013, s.168.

${ }^{30}$ Terim olarak tazir; "hakkında had cezası bulunmayan suç ve günahları işleyenler için verilen, miktarı ve keyfiyeti naslarla kesin olarak belirlenmiş önleyici, caydırıcı ve ıslah edici cezalardır." Mustafa Yıldırım, "İslam Hukukunda İçki İçme Suçu ve Cezası", D.E.Ü. Ilahiyat Fakültesi Dergisi" Sayı: XIII-XIV, İzmir 2001, s.42.

${ }^{31}$ Erdal, Demirci, Sivri, " Meşrutiyet'ten Cumhuriyet'e Türkiye'de içki ile Mücadele, s.11.

32 iki erkek şahit, suçlunun suçunu itiraf etmesi, sarhoşluk halinin ispat edilmesi gibi durumlarda bu suçun cezası tatbik edilirdi. Ama küçükler, deliler, gayrimüslimler ve sonradan Müslüman olup bu yasağı bilme olanağı bulamayanlara bu ceza

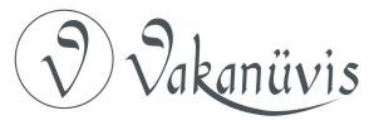


etkileri olmuştur. Örneğin; Müslümanlardan bazıları İslam'ın sadece şarabı yasakladığını ve diğer içkileri serbest bıraktığını düşündüklerinden dolayı rakı içerler. Böylece hem zevklerinden mahrum kalmamış olurlar hem de dinlerine saygı göstermiş olurlar. Bu nedenle Türkiye'de şarap tüketimi, çok kaliteli şaraplar üretilmesine karşın sınırlı kalmıştır. Yine bir diğer örnek Ramazan ayında içkiye ara verilmesidir. Dini görevlerini yerine getirmeyenler Ramazan ayı geldiğinde içkiye tamamıyla ara verirler ve böylelikle dinlerine gösterilmesi gereken saygıyı unutmamış olurlar ${ }^{33}$.

\section{Osmanlı'da Müskirat Meselesi}

Osmanlı Devleti'nde Müslümanların içki üretmesi, tüketmesi ve alım-satımını yapması yasak kapsamındaydı. Osmanlı Devleti, içinde sadece Müslümanların varlığını sürdürdüğü bir devlet olmayıp farklı dinlere mensup kişilerin de yaşadığı bir devletti. Gayrimüslimler için içki, inançları gereği yasak değil tam aksine "rızık" türünden sayılırdı. Bu doğrultuda, Osmanlı Devleti sınırları içerisinde gayrimüslimlerin içki üretimini, nakliyesini ve ticaretini yapmalarına izin verilmiş fakat belli şartlara bağlanmıştı. Osmanlı Devleti'nin içkiye yaklaşımı şer'i hukuk çerçevesinde değerlendirildiğinden dolayı Müslümanlara yasak olmasına rağmen kaçak yollardan da olsa bazı kimselerin içki kullandığı bir gerçektir ${ }^{34}$. Konu ilgili geniş bir araştırma yapan îhsan Erdinçli bu durumu, İslam devleti olması hasebiyle yasak olan içki ve diğer yandan içkinin tüketildiği meyhanelerin mevcudiyetinin karşımıza ilginç bir örnek çıkardığını zikretmektedir ${ }^{35}$.

Devlet, bazı dönemlerde içki ile ilgili sert tedbirler almak durumunda kalmışlardır. Kimi dönemlerde kanunnamelerde içki hususuna değinilmiş ve cezası belirtilmiş kimi dönemlerde de içki nizamnameleri çıkarılmış ve içki hususuna açıklık getirilmiştir. Osmanlı

uygulanmazdı. İlhan Akbulut, "İslam Hukukunda Suçlar ve Cezalar", AÜHFD, Ankara 2003, Cilt: 52, Sayı:1, s.176.

${ }^{33}$ Erdal Atabek, Alkol ve Insan, 2. Baskı, Kelebek Yayınları, İstanbul, 1983, s.226-227.

${ }^{34}$ Osman Köse, "XVIII. Yüzyıl Sonlarına Doğru Rus ve Avusturya Savaşları Esnasında Osmanlı Devleti'nde Bir Uygulama: İstanbul'da Fuhuş ve İçki Yasağı", Turkish Studies Türkoloji Araştırmaları Dergisi, Volume 2/1, Winter 2007, s.116-117.

35 ihsan Erdinçli, Keyif, Günah ve Suç Arasında Osmanlı'da Meyhaneler ve Müdavimleri, Tarih Vakfı Yurt Yayınları, İstanbul, Haziran 2021, s.20.

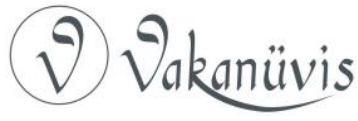


padişahlarının içki ile olan münasebetlerine ve içkiye karşı ı̧ıkardıkları kanunnamelere bakıldığında ilk bilgilere Aşıkpaşazade Tarihi'nde rastlamaktayız. Nitekim Aşıkpaşazade Tarihi'ndeki iki dörtlük halinde yazılmış olan nazım ifadeler bize o vakte kadar padişahların içki kullanmadıklarını ve Yıldırım Bayezid'in Sırp Prensesi olan eşiyle ilk buluşmasında içki kullandığını anlatmaktadır. ${ }^{36} \mathrm{Bu}$ ifadeyi destekler nitelikte olan bir diğer bilgiyi de Paul Wittek vermektedir. Paul Wittek, Osmanlı sarayına şarap içme alışkanlığını Yıldırım'ın eşi Sırp Prensesi Olivera'nın getirdiğini söylemektedir ${ }^{37}$. Buna karşın Halil İnalcık içkiye karşı ilk tepkinin Yıldırım Bayezid tarafından verildiğini söyler. ${ }^{38}$ Yine II. Mehmed'in babası II. Murat, tahtı oğluna bırakıp Manisa'ya döndüğünde "iyş $u$ işrete meşgul olmak" üzere döndüğünü ve yanında şarapdar Hamza Bey ile İshak Paşa'yı da aldığı ifade edilir ${ }^{39}$. Fatih Sultan Mehmet döneminde içkinin cezası şöyle belirtilmiştir: "Eğer biregû hamr içse Türk veya şehirlü olsa, kadı ta'zir ura. Iki ağaca bir akçe cürm alına ${ }^{40}$." Burada kişi, kadının verdiği tazir ile cezalandırılacaktı ve bu cezalar sadece Müslümanları kapsamaktaydı. II. Bayezid döneminde 1507 yılında çıkan bir nizamnamede padişah

\footnotetext{
${ }^{36}$ Şarab u hem kebab meclis kuruldu

Ali Paşa dedi han anı gözle

Şarab içmeğine Han Beyazi'ün

Buna dak Âl-i Osman içmediler
}

Kâfir kızı gelüğ kadeh sürüldü

Ki ne meclis bu sohbetde olundu

Ali Paşa kâfir kızı bulundu

Nola Osman kâfirle çok olundu. Âşıkpaşazâde Tarihi, Osmanlı Tarihi (1285-1502), (Haz: Necdet Öztürk), Bilge Kültür Sanat, İstanbul, 2013, s.94-95

37 Namık Sinan Turan, "Geleneksel Toplumda Yasağın Cazibesi Osmanlı Toplumunda İçki", Evrensel Kültür, 2012, s.39.

38 "Yıldırım Bayezid, Ulu Camii temelini attığı zaman "şurb-i hamrdan vaz-gelip ulemâ-i 'izâm ve meşâyih-i kirâmla musâhebet edüp icrâ-yi şer'i kavîm üzere müstakim olup âlemi mezâlimden hâlı'” kıldı." İnalcık, Has-Bağçede 'Ayş u Tarab, s.298; Erdal, Demirci, Sivri, " Meşrutiyet'ten Cumhuriyet'e Türkiye'de İcki ile Mücadele, s.14.

${ }^{39}$ Halil İnalcık, Fatih Devri Üzerine Tetkikler ve Vesikalar, Türk Tarih Kurumu Yayınları, Ankara, 2014, s.81; Namık Sinan Turan, "Geleneksel Toplumda Yasağın Cazibesi Osmanlı Toplumunda İçki", s.39.

40 Ahmed Akgündüz, Osmanlı Kanunnâmeleri ve Hukukî Tahlilleri, I. Kitap/ Osmanlı Hukukuna Giriş ve Fatih Devri Kanunnameleri, FEY Vakfı Yayınları, İstanbul, 1990, s.349.

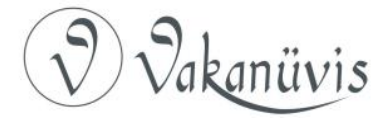


Ulûfeci Hasan isminde bir görevliye talimatname verip Bursa'ya gönderiyor, Bursa'nın sancakbeyini ve kadısını konuyla ilgili sert bir dille uyarıyordu. Padişahın bunu yapmasındaki esas neden, Bursa'da toplantılarda, kasabalarda ve düğünlerde içki içildiği bilgisinin kendisine ulaşmasından kaynaklanmaktaydı ${ }^{41}$. Yine Kanuni döneminde sert içki yasağı getirilmesine rağmen II. Selim döneminde getirilmemiş ama her iki padişah döneminde de içki ticaretinden çeşitli vergiler alınmıştır ${ }^{42}$. Bu yasaklamaların 17 ve 18 . yüzyıllarda da devam ettiği görülmektedir. Nitekim III. Mehmet ${ }^{43}$, I. Ahmet ${ }^{44}$ ve IV. Murat ${ }^{45}$ dönemlerinde de içki yasaklamaları mevcuttur ki IV. Murat döneminde olan yasakların çok sert bir biçimde uygulandığı bilinmektedir. Kendisinden önceki içki yasaklarına benzemeyen bir yasak mevcuttur IV. Murat döneminde. Kahve ile beraber tütün, afyon ve şarabın tüketilmesine de izin verilmiyordu. Bunun için padişah, bostancıları görevlendirmiş ve kendisi de i̇stanbul'da gezip yasağı çiğneyenleri aman vermeden öldürmüştü46 ${ }^{46}$ II. Süleyman zamanında (1687-1691) ekonomik olarak hazinenin gelir kaybına uğramaması için içki yasağına son verilmiştir fakat daha sonra yeniden yasaklanmıştır ${ }^{47}$. Lale Devri

\footnotetext{
${ }^{41}$ Ahmed Akgündüz, Osmanlı Kanunnâmeleri ve Hukukî Tahlilleri, II. Kitap/ II. Bâyezid Devri Kanunnameleri, FEY Vakfı Yayınları, İstanbul, 1990, s.232-233; Nermin Taylan, Osmanlı'da Yasaklar, Çınaraltı Yayınları, İstanbul, 2019, s.92-93

${ }^{42}$ Erdal, Demirci, Sivri, " Meşrutiyet'ten Cumhuriyet'e Türkiye'de içki ile Mücadele, s.15.

43 III. Mehmet zamanında 1601 yılında "Şevval ayında yasâğ-ı sultani ile (padişah yasağı ile) ümmül hâbâis (fenalıkların anası) adlı fahişe (yâni içki) tesettür ihtifa edip (örtünüp, gizlenip) Hamr Emaneti (şarap emaneti) kaldırıldı." Naima Mustafa Efendi, Naima Tarihi, I, (Çev. Zuhuri Danışman) Bahar Matbaası, İstanbul,1967, s.259

44 "bu sene cümâda'l-âhiresinde, şeriati ihya eden şenaatleri kaldıran dindar padişah fitne ve şürura sebep olan hamr (içki) denilen ümmül-hebaşisi (fenalıkların anasını) memalik-i Osmaniye'de tamamen kaldırdılar." Naima Mustafa Efendi, Naima Tarihi, II, (Çev. Zuhuri Danışman) Bahar Matbaası, İstanbul,1968, s.646

45 istanbul'a girer girmez içki yasak olup, bütün meyhaneleri yıktırıp bu hususta pek ileri gidildi. Ve bizzat kendileri gece ve gündüz gezip buldukları sarhoşları katlederlerdi. Hattâ birini bizzat ok ile urup denize düşünce, helâk oldu deyû geçtiler. Sonra ol biçare çıkıp kurtuldu. Naima Mustafa Efendi, Naima Tarihi, III, (Çev. Zuhuri Danışman) Bahar Matbaası, İstanbul,1968, s.1272-1273.

${ }^{46}$ Refik Ahmet Sevengil, İstanbul Nasıl Eğleniyordu?, İletişim Yayınları, İstanbul , 1985, s.21; Bozkurt, "Türk Içki Geleneği" s.47.

47 "icçi", Dünden Bugüne İstanbul Ansiklopedisi, Tarih Vakfı Yayınları, İstanbul, 1993, Cilt: 4, s.132.
}

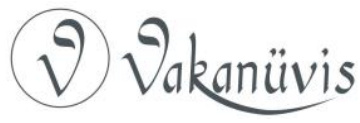


(1718-1730) ise içkinin serbest bırakıldığı ve meyhanelerin rahat bir dönem yaşadığı zaman olmuştur. 1740'ta I. Mahmut döneminde ise yasak tekrardan geldi ve İstanbul'a içki ithali yasaklandı ${ }^{48}$. Ve yine III. Selim döneminde de sert bir içki yasağı tatbik edilmiştir ve bu yasağı Câbî Efendi şöyle anlatmıştır: "Sultan Selim ne kadar meygede var ise kapattı, şarap, rakı ve onlara benzer ne kadar içki varsa hepsini şiddetle yasak etti; yasağa rağmen içki kullanan birkaç kişi idam olundu; Rumlara ve Ermenilere patrikleri, Yahudilere de hahambaşı, Müslümanlara içki vermemeleri ve satmamaları için muhkem tembih ettiler, aksi takdirde idam olunacaklarını bildirdiler. Ayyaşların hali kötüleşti ama çok geçmedi, el altından içki satanlar da peyda oldu. Mesela bir adam eline bir bülbül kafesi alıp sokağa çıkar, sorana 'Bülbülümü gezdirmeye giderim...' derdi, amma kafesin içine barsak konulmuş, barsaklar da rakıyla doldurulmuş. Kafesin ağırlığından şüphelenen zabıta herifi yakalamış, rakıyı meydana çıkarmış. Ağa kapısına götürmüşlerse de şefaatçileri çıkıp kurtulmuş..."49 III. Selim'in içki yasağı ile ilgili uyguladığı tedbirlerdeki esas gaye asayiş ve nizamı sağlama kaygısıydı. Aynı kaygı II. Mahmud içinde geçerliydi ${ }^{50}$.

Tanzimat döneminden sonra devletin bazen açtığı bazen kapattığı meyhaneler ve benzeri eğlence mekânları büyük bir özgürlüğe kavuşmuştur. Nitekim meyhaneler i̇stanbul'da ciddi manada çoğalmıştı ${ }^{51}$. Tanzimat ve Islahat Ferman'larının ilân edilmesinden sonra meyhanelerin tamamen kapatılması gibi durumlar ortadan kalktığı gibi yürürlüğe konulan nizamnamelerle ${ }^{52}$ birlikte meyhanelerin

\footnotetext{
48 "içki Yasağı", Ana Britannica, Cilt: 11, s.477.

${ }^{49}$ Reşad Ekrem Koçu, Tarihimizde Garip Vakalar, Doğan Kitap, 5. Baskı, İstanbul, 2016, s.50.

50 ihsan Erdinçli, Keyif, Günah ve Suç Arasında Osmanlı'da Meyhaneler ve Müdavimleri, s.225.

${ }^{51}$ Sevengil, Istanbul Nasıl Eğleniyordu?, s.170.

52 İçki hakkında çıkarılan nizamnameler 8 tanedir. Bunlar; 1278/1861, 1283/1867, 1297/1881, 1303/1886, 1305/1888, 1305/1888 (Bir öncesine ek olarak çıkarıldı), 1322/1904, 1322/1904; Erdal, Demirci, Sivri, “ Meşrutiyet'ten Cumhuriyet'e Türkiye'de Içki ile Mücadele, s.20-24; Öztürk, "'XIX. Yüzyıl Arşiv Belgelerine Göre Osmanlı Devleti'nde içki Yasakları", s.112-138.
}

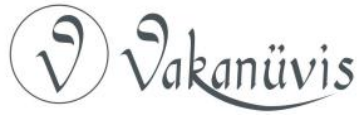


nerelere açılacağı gibi hususlar büyük ölçüde belirtmiştir ${ }^{53}$. Bu nizamnamelerden 15 Ağustos 1283/28 Ağustos 1867'de çıkarılan "Dersaadet ve bilâd-ı selâse ile taşralarda kadeh ve kıyye ile müskirat füruht edenlerden işbu bin iki yüz seksen üç senesi teşrin-i evvel ve rumi on ikinci gününden itibaren alınacak resm-i bey'iyeyes dair olup ahkâm-ı mündericesi gerek devlet-i aliyye gerek düvel-i ecnebiye tebaası hakkında bilâ-istisna mer'iyyülicra olunacak nizamnamedir" adıyla bildirilen düzenlemeler meyhaneler hakkında geniş bilgiler içermektedir. Bu nizamnameye göre; açılacak meyhanelerin cami, tekke ve medrese gibi dini mekânların olduğu bölgelerle arasındaki mesafe yüz arşından fazla ise açılmasına izin verilecekti. Yine yerli, yabancı ve taşradan meyhane açma talebinde bulunacak kişilerin nerelere başvuracağına açıklık getirilerek ilaveten kadeh ve kıyye ile içki satan mekânlardan yıllık bey'iye vergisi alınacaktı. Bu verginin alınması da Zecriye Nezareti'nin kontrolünde olacaktı. Öte yandan müskirat satacak olan mekânların hangi nitelikler taşıyacağı da belirtilerek ve içki satmayan lokantalar dışındaki tüm içki satan yerlerden de vergi alınacakt ${ }^{54}$.

Sultan II. Abdülhamid döneminde de cami ve mescitlere yakınlığı dolayısıyla meyhaneler kapatılıyordu. Mesafe tayini ile alakalı sıkıntılar belgelere de yansımıştı. 1894 tarihine ait bir iradede, padişah fermanı gereği aynı sebeple kapatılan meyhanelerden biri de Yunanlı Estalyanos Dimitraki Girifornadyos'un meyhanesiydi. Fakat gediklij ${ }^{55}$ bir meyhane olmasından dolayı ileriki bir tarihte gerekli işlemlerin yapılmasına karar verilmiş ve bu tarihe kadar geçici olarak içki satışı yapmasına Bâbıâli müsaade etmiştir. Meyhanenin konum olarak Mesih

\footnotetext{
53 Uğur Akbulut, "Meyhanelerle Mukaddes Mekânlar Arasında Mesafe Tayini: Sultan II. Abdülhamid Devri İstanbul'undan Örnekler", Karadeniz Araştırmaları, Bahar 2016, Sayı: 49, s.215.

${ }^{54}$ Erdal, Demirci, Sivri, " Meşrutiyet'ten Cumhuriyet'e Türkiye'de içki ile Mücadele, s.21.

55 İçki satışı yapılan meyhaneler ya gedikli meyhanelerdi ya da koltuk meyhanelerdi. Gedikli meyhanelerde ruhsatla çalışan ve ruhsatı devletten alan meyhanelerdi. Ayrıca gediğin üstünde o devrin padişahının tuğrası vardır ve bu yüzden gedikli meyhanelere "selatin meyhane" de denmiştir. Koltuk meyhaneleri ise ruhsatsız ve kaçak çalışırdı. Tabi kolluk kuvvetlerine "görme beni" ücretini vererek. Reşad Ekrem Koçu, "Eski istanbul'da Meyhaneler ve Meyhane Köçekleri", 4. Baskı, Doğan Kitap, İstanbul, 2015, s.14.
}

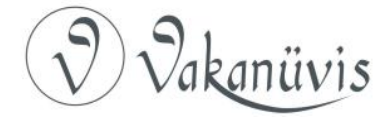


Ali Paşa camiine kırk adım yakınlığında olmasına ilaveten civar halkının da şikâyetleri dolayısıyla açık kalması uygun değildi. Usulen gedikli bir meyhanenin kapatılması da uygun değildi. Üstelik Yunan sefareti de burada içki satışı yapılması yönünde talepte bulunmuştu. Bu çetrefilli mesele ancak ve ancak gediğin satın alınmasıyla çözüleceğinden, önce gediğin kime ait olduğu, değerinin ne kadar olduğu ve son olarak satın alınması gerektiği belirtiliyordu ${ }^{56}$.

II. Abdülhamit Döneminde içki, bir takım aile olaylarına da sebebiyet veriyordu. Konu ile ilgili geniş bir araştırma yapan yazar Roger A. Deal'in II. Abdülhamit Dönemi'ne ait çalışmasında buna dair örneklere rastlamak mümkündür. Örnek olarak, eve sarhoş vaziyette gelen Ahmet Sezai Efendi kayınvalidesi ile tartışmıs ve onu tabancayla yaralamıştır. Olay gerçekleştikten birkaç gün sonra polise intikal etmiştir ${ }^{57}$.

\section{Meşrutiyet Dönemi'nde İçkinin Tesiriyle Memurların Çıkardığı Asayiş İhlalleri}

II. Meşrutiyet döneminde içki ile ilgili meselelere karşı devlet bazı önlemler almaya çalışarak içki satan esnafı denetimlere tabi tutmuş ve ruhsatsız bir şekilde dükkân açan esnafa bazı cezalar vermiştir ${ }^{58}$. Bununla birlikte kutsal mekânlarla meyhane arası mesafelere dikkat edilmiş, içki meselesi ve vergilerle ilgili durumlar yasal düzenlemelerle belirtilmiştir.

II. Meşrutiyet döneminde toplumsal anlamda alkole karşı ilk tepkilerin geldiği görülmektedir. Bu ilk tepkilerle beraber tütün, alkol ve madde bağımlılığı için Karadeniz Ereğlisi Osmanlı içki Düşmanları Cemiyeti, Osmanlı Men'-i Müskirat Cemiyeti, İçki Düşmanları Cemiyeti ve Hilâl-i Ahdâr Cemiyeti gibi kuruluşların faaliyete geçtiği görülmektedir ${ }^{59}$. Bunun yanında Hilâl-i Ahdâr (Yeşilay), Hilâl-i Ahmer

\footnotetext{
56 Vahdettin Engin, "Sultan Abdülhamit ve İstanbul'u", Simurg Yayınları, İstanbul, 2001, s.62-63.

${ }^{57}$ Roger A. Deal, Namus Cinayetleri Sarhoş Kavgaları II. Abdülhamid Döneminde Şiddet, Çeviri: Zeynep Rona, Kitap Yayınevi, İstanbul, Mart 2017, s.152.

58 İnce, "ikinci Meşrutiyet Döneminde Müskirat ve Müskirat Satan Yabancı Esnafa İzin Verilmesi, s.422.

${ }^{59}$ Erdal, Demirci, Sivri, " Meşrutiyet'ten Cumhuriyet'e Türkiye'de içki ile Mücadele, s.27.
}

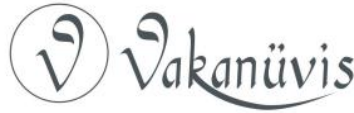


(Kızılay) gibi kurumlar çıkardıkları yayın organlarıyla bu cemiyetler gibi bilinçlendirme faaliyetlerine katkıda bulunmuştur ${ }^{60}$. Tüm bu tedbirler ve alkolizm mücadelesine rağmen içki, toplumsal hayatta pek çok sorun yaratmaya devam ederek ailevi sorunlardan kamusal hayata kadar çoğu yerde varlığını hissettirmiştir.

Alkolün kamu çalışanları üzerindeki etkisi de azımsanmayacak derecede çoktur. Orduda, bahriyede, askeri okullarda, emniyet teşkilatında ve çoğu karakollarda içki yüzünden olaylar meydana gelmiş ve bunlar adli işlemler ile neticelenmiştir. Kimi memurlar görevi başındayken olaylara karışmış, kimileri göreve alkollü bir şekilde gelmiş, kimileri de içki içtikten sonra sarhoşluğun da etkisiyle yüz kızartıcı suçlar işlemiştir. Bu suçlara karşı mahkemelerde yargılanmışlar ve bazı cezalara çarptırılmışlardır. Suçları sabit olan memurlara pranga, kürek, tenzil-i rütbe, uyarı, meslekten ihraç ve hapis cezası gibi cezalar verilmiştir.

Döneme ait olaylara bakıldığında kamusal hayatta pek çok sorunun yaşandığı çarpıcı örnekler karşımıza çıkmaktadır. Bu örneklerin büyük çoğunluğunun ortak özelliği ise içkinin kişiye verdiği sarhoşluğun etkisiyle çeşitli olaylara karışması ve dolayısıyla asayişin ihlal edilmesi ile sonuçlanmıştır. Diğer örnekler de maddeler halinde sınıflandırıldığında ise aynı suçu tekrar tekrar işleyen memurlar, vazifeye veya askeri okula sarhoş gelenler, görevi başında içki içenler ve memurluğun asaletine yakışmayan biçimde işret âlemlerine giren memurlar şeklinde sınıflandırabiliriz.

1910 tarihli Sadâret Dairesinin Tahrîrât Kaleminden Harbiye Nezâret-i Celîlesine gönderilen yazıda işret eden iki memurun birden fazla cezaya çarptırılmalarına karar verilmiştir. Bahsi geçen bu iki kişi ikinci Ordu Nizamiye 14. Alayı'nın musika onbaşısı Karahisarlı Mustafa b. Mehmed ile altıncı hayme efradından Bursalı Halil b. Mehmet Cum'a'dır. İçki içip bir kişiye cebren cinsel saldırı girişiminde bulunmaları üzerine bu iki kişinin askeri ceza kanununun ilgili maddelerine göre cezalandırılmalarına karar verilmiş ve bu doğrultuda Mustafa ve Halil'in üçer sene pranga cezasına çarptırılmalarına,

60 Öztürk, ““XIX. Yüzyıl Arşiv Belgelerine Göre Osmanlı Devleti’nde İçki Yasakları”, s.163.

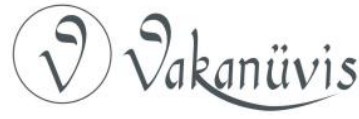


cezaları bitince tekrar nefer olarak kaydedilmelerine hükmedilmiştir. Illaveten Mustafa onbaşının rütbesinin indirilmesine ve işret edip âlem yaptıklarından dolayı da her iki askerin kırk beşer gün hapis cezasına çarptırılmalarına karar verilmiştir ${ }^{61}$.

İçki içtikten sonra silahların kullanıldığı ve dolayısıyla asayişin tehdit edildiği vakalar da oluyordu. 1919 yılında İstanbul Vilayetinden Dâhiliye Nezaretine gönderilen bir yazıda içkinin sebep olduğu ve yüz kızartıcı suçların döndüğü bir olayın cereyan ettiği görülmektedir. Olay, Veliefendi Çayırı'nda bir hırsızlık vakasının olduğu Kaymakam Nazmi Bey tarafından beyan edilmesi üzerine görevlendirilen Makriköy Merkez takım kumandanının suç mahalline intikal etmesi ile başlamıştır. Kumandan olay yerine intikal ettiğinde her şeyin yerli yerinde olduğu ve herhangi bir şekilde hırsızlık olayının vuku bulmadığını anlamıştır. Fakat meselenin başka bir yerde meydana geldiği, olayın zannedildiği gibi bir hırsızlık olayı olmadığı, askeriyeden Bekir ve Sami ile Onbaşı Hüseyin'in getirmiş olduğu üç kadınla işret âlemi yapmasından kaynaklandığı geç olmadan anlaşılmıştır. Sonrasında askerlerden Bekir, olay yerine gelen inzibatlara iki el ateş etmiştir. Bunun üzerine herhangi bir hadiseye meydan verilmeden işret eden asker ve kadınlar derdest edilmiş ve adı geçen askerler İstanbul Muhafızlığına, kadınlar ise Makriköy Polis merkezine teslim edilmiştir $^{62}$. Bu üç askere işledikleri suçtan dolayı ne ceza verildiği bilinememektedir fakat en iyi ihtimalle yüz kızartıcı suça karıştıklarından, inzibatlara silah çekmelerinden ve haliyle askerlik mesleğinin ağırlığına uygun hareket etmediklerinden ötürü mesleklerinden ihraç edilmiş olmaları imkân dâhilindedir.

İçkinin vermiş olduğu başıbozukluğun tesiriyle silahların kullanıldığı bir başka vaka 1909 yılında Bahriye Nezaretine gönderilen yazıda bildirilmiştir. Gece saat üç sularında Bahriye kolağalarından Rafet Efendi'nin çok kötü sarhoş olduğu halde eve dönüşü sırasında Taksim Caddesi'nde iki el ateş etmiştir. Rafet Efendi bu davranışı yüzünden uyarılmıştır. Gönderilen yazıda bunun kabul edilemeyecek bir hareket

61 BOA, BEO, 3737/280250. (H. 12 R 1328/ M. 10 Mayıs 1910)

62 BOA, DH. EUM. AYŞ, 16/78. (H. 26 L 1337/ M. 25 Temmuz 1919)

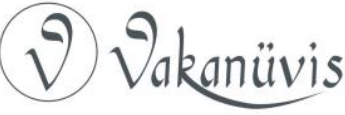


olduğu bildirilmiş ve bunun gibi bilinç dışı davranışlara son vermesi gerektiği anlatılmıştır ${ }^{63}$.

Yine sarhoşluğun verdiği kendini kaybetme haliyle işlenen suçlardan bir tanesi 1908 yılında yaşanmıştır. Polis çavuşlarından Hasan Efendi'nin gece vakti Avusturya tebaasından Eleni'nin evinin kapısına sarhoş halde dayanması, rezillik çıkarması ve yine sokaklarda nara atması kendisinin meslekten ihracına sebep olmuş ve ayrıca bu gibi davranışları sergileyen kişilerin tekrar memuriyete iade edilmesinin kesinlikle caiz olmadığı Üsküdar Mutasarrıflığınca görüş olarak Zabıta Nezaretine bildirilmiştir. ${ }^{64}$.

İçkinin bazı ailevi sorunlara neden olması da kaçınılmazdır. Bu sorunlar tipik aile geçimsizliğinden başlamakta ve cinayetlere kadar da ulaşmaktadır. Yine içkinin sebep olduğu bir asayiş olayı bu sefer aile içi sıkıntılara sebebiyet vermiştir. 1908 yılında haddehane üçüncü sınıf öğrencisi olduğunu beyan eden Hüsmen Efendi b. Tevfik, bir cumartesi gecesi sarhoş iken mahalle arasında nara atmakta ve bir takım rezalet işlere cüret etmekte olduğu haber alındığında Eyüp'teki evine götürülmüş fakat ailesi tarafından kabul edilmemiştir. Bunun üzerine Feshane Nizamiye karakolhanesine teslim edilmiştir ${ }^{65}$. Bu olayda Hüsmen Efendi'nin eve kabul edilmemesinde bazı rezalet işlere girişmesi etkili olmuş olabilir fakat netice olarak bu soruna içkinin neden olduğu aşikârdır.

Kurtuluş Savaşı yıllarında yaşanan bir asayiş olayına bu sefer İstanbul'u işgal altında tutan İngilizler de dâhil olmuştur. İngilizler, Nuruosmaniye'de geçen bu olaya Kemerburgaz takımının merkez karakol kumandanı Başçavuş Sermed ile hayvan sirkati (hırsızlığı) suçundan sanık olan Muammer'in beraberce Osmaniye telsiz telgraf istasyonu civarında bazı şahıslara saldırıp onları soymaya kalktıkları ihbarı üzerine dâhil olmuşlardır. Yapılan ihbar sonucu Başçavuş Sermed ve Muammer'i İngilizler derdest etmiş ve Galata'daki Düvel-i İtilafiye Komiserliğine teslim etmiştir ${ }^{66}$. Yaşanan bu olay bize döneme dair bazı ipuçları vermektedir. Genelde İstanbul'un özelde ise Osmaniye telsiz

\footnotetext{
63 BOA, ZB, 314/7. (R. 21 Te 1324/ M 3 Kasım 1909)

${ }^{64}$ BOA, ZB. 83/39. (R. 25 A 1324/ M. 7 Eylül 1908)

65 BOA, ZB. 314/4. (20 T 1324/ M. 2 Kasım 1908)

${ }^{66}$ BOA, DH. EUM. AYŞ, 21/87. (H. 19 Z 1337/ M. 15 Eylül 1919)
}

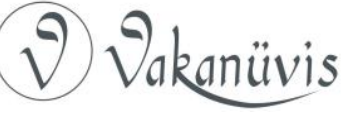


telgraf istasyonunun Mütareke yıllarının başlarında İngilizler kontrolünde olduğu anlaşılıyor. Bir Osmanlı askerinin içki içip asayişi tehdit ettiği için İngilizler tarafından yakalanıp İtilaf Devletleri Komiserliğine teslim edilmesi, olayın geçtiği tarihte Osmanlı Devleti'nin nasıl güç durumda olduğunu göstermektedir. Bu iki kişinin akıbetlerinin ne olduğu ve Osmanlı Devleti'nin bu asayiş olayına nasıl dâhil olduğu hakkında herhangi bir bilgi ne yazık ki mevcut değildir.

İçkiyi mesai saatleri dışında kullanan memurlar bir ölçüde anlaşılabilir olsalar da görevi başında bunu yapan memurlar da ne yazık ki mevcuttu. Nitekim İstanbul'da bir polis memuru olan Hayri Efendi de bunlardan birisiydi. Kendisinin ifadesi alındığında her ne kadar suçunu inkâr ediyor olsa da şahit beyanlarıyla suçu sabit görülmüştür. Memur olduğu karakolda bir Pazar günü konuşamayacak ve kendini idare edemeyecek derecede sarhoş halde görülmüş ve karakoldaki komiser muavini ile iki polis memuru tarafından ihbar edilmiştir. 14 seneden beri polislik yaptığı halde bir gün bile vukuatı bulunmayan Hayri Efendi'nin polislik mesleğinden kaydı silinerek meslekten atılmıştır ${ }^{67}$. Benzer bir diğer vaka Çinili Merkez Serkomiserliği Karakolunda gerçekleşmiştir. Musa ve Ömer isminde iki memur karakolda işret âlemi yapmış, göreve gelmeme ve nasihatlere kulak asmama gibi suçlarından ötürü de haklarında gerekli işlemler başlatılmıştır ${ }^{68}$.

Görevde olmasına aykırı bir şekilde içki içen memur olduğu gibi bazen de aynı suçu birkaç kez işleyen memur da vardı. Nitekim içki içip işret ettiği için hapse mahkûm olan Eczacı Yüzbaşı Şahabettin Efendi de mahkûmiyetinden sonra tekrar aynı suçu işlediği sabit olduğu için askerlik mesleğinden kovulmasına hükmedilmiştir ${ }^{69}$.

Bu son örnekle beraber yukarıda anlatılan tüm olayların yegâne müsebbibi olan alkol, içildikten sonra insanları yoldan çıkarmış ve

\footnotetext{
67 BOA, DH. EUM. SCL. 11/19. (8 Ca 1329/ M. 7 Mayıs 1911)

68 BOA, ZB, 122/4. (R. 25 Mart 1325/ M. 7 Nisan 1909)

${ }^{69}$ BOA, BEOBOA, ZB. 314/4. (20 T 1324/ M. 2 Kasım 1908)

${ }^{69}$ BOA, DH. EUM. AYŞ, 21/87. (H. 19 Z 1337/ M. 15 Eylül 1919)

${ }^{69}$ BOA, DH. EUM. SCL. 11/19. (8 Ca 1329/ M. 7 Mayıs 1911)

${ }^{69}$ BOA, ZB, 122/4. (R. 25 Mart 1325/ M. 7 Nisan 1909)

69 BOA, BEO, 4364/327295. (H. 6 N 1333/ M. 18 Temmuz 1915)
}

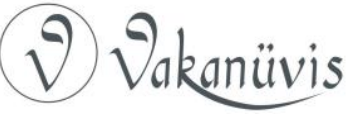


normal zamanda insanların yapmayacağı davranışlar sergilemelerine sebebiyet vermiştir. İçkiyi sürekli kullanan kişilerde meydana gelen birtakım ruhi ve akli bunalımlar onlara bir daha telafi edilmesi zor kabahatler işlettirmiştir. Zaten her gününü suçlu aramakla geçiren polis ve askerin bir de içki yüzünden suçlara karışması meselenin ne kadar önemli olduğunu göstermesi açısından dikkate değer bir husustur. Tabi ki devlet her ne şartta olursa olsun bu suçları karşıııksı bırakmamış, kimileri hakkında gerekli muameleyi uygulamış kimileri hakkında da hapis ve meslekten ihraç gibi cezalar vermiştir.

\section{Sonuç}

Eski devirlerden beri kullanılagelen içki, çeşitli dinler tarafından tüketimi serbest bırakılırken kimi inançlarda da dini ritüel olarak kullanılmıştır. İslam dininin içkiye bakış açısı ise diğer dinlerden farklı olmuş ve kesin hükümlerle yasaklanmıştır. Osmanlı Devleti içerisinde yaşayan Müslümanların içki kullanması yasak kapsamında değerlendirilirken gayrimüslimlerin içki üretmesi, ticaretini yapması ve meyhane açması gibi durumlar belli şartlarla mümkün kılınmıştır.

Devlet, içki konusundaki düzeni sağlama adına dönem dönem kanunnameler ve nizamnameler çıkarmıştır. Bunun yanında II. Meşrutiyetle beraber alkolizmle mücadele adına toplumsal anlamda bir tepki mahiyetinde olan cemiyetler kurulmuş ve buna ek olarak gazete ve mecmualarda bilinçlendirme faaliyetleri yürütülmüştür. Tüm bunlara rağmen Osmanlı Devleti'nin içkiye dair uygulamaları tam anlamıyla sorunsuz bir şekilde yürütmesi ve kontrol altında tutması mümkün olmamıştır. İçki ile ilgili olarak meyhanelerin açılma şartları ve konumları ile ilgili problemler, müskirat esnafının çıkarılan yasaklara ve kurallara uymaması, alkol tüketiminin ailede yarattığı ekonomik ve sosyal sorunlar her daim varlığını sürdürmeye devam etmiştir.

Devletin içki kapsamında uğraştığı alanlardan bir tanesine de kamu memurları dâhil olmuştur. Özellikle II. Meşrutiyet Döneminde, devlet içki yüzünden vatandaşına tedbir niteliğinde uyguladığı düzenlemelere ek olarak bir de kendi kurumlarında görev yapan memurlarla uğraşmak zorunda kalmıştır. Cümle Osmanlı mülkünde yaşayan vatandaşların canını, malını ve namusunu korumak, onların toplumsal huzurunu sağlamak ve asayişi temin etmekle görevli olan polis ve asker, kullandıkları içkinin etkisiyle çeşitli suçlar işlemişlerdir. Bu çalışanlar,

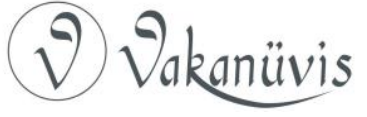


alkolün vücuda verdiği hoşluğun tesiriyle o anki muhakemesini kaybedip çeşitli suçlara karışmışlardır. Kimi zaman belindeki silahı etrafa sıkmış, kimi zaman olay yerine gelen kolluk kuvvetlerine silah çekmiş, kimi zaman da vatandaşa saldırıp onları soymaya kalkmıştır. Hatta daha ileri giderek görevi başındayken sarhoş halde görülmüş, vatandaşa cinsel taciz girişiminde bulunmuş ve işret âlemlerine girerek devlet memuru profiline uymayan vaziyetlerde görülmüşlerdir. İşledikleri bu suçlara karşılık olarak memurlara çeşitli cezalar uygulanmış, doğal olarak bir ölçüde de caydırıcılık hedeflenmiş ve devlet kurumlarının itibarına olan güvenin sarsılmasının önüne geçilmeye çalışımıştır. Devletin II. Meşrutiyet Dönemi'nde uyguladığı cezalara bakıldığında sadece bu suçların önüne geçilmeye çalışıldığı ve tedbirlerinde bu yönde alındığı görülmektedir. Dolayısıyla idari yönetim içkiyi kökten yasaklama gibi bir uygulamaya başvurmamıştır. Döneme ait verilen örneklerde verilen cezalara bakıldığında, hiçbir suça karışmadan sadece işret ettiği gerekçesiyle bile memurlar hapis cezasına çarptırılmıştır. Fakat işret etme suçu ileri boyutlara vardığında meslekten ihraç gibi cezalara başvurulmuştur. Bir özgürlük ortamının olduğu bilinen II. Meşrutiyet Dönemi'nin sağladığı rahatlığa devlet memurlarının da dâhil olması hiçbir sorun oluşturmamakla birlikte verilen cezalar sadece asayişin teminini sağlama amaçlı gerçekleştirilmiştir.

\section{Kaynakça}

\section{Arşiv Belgeleri}

Türkiye Cumhuriyeti Cumhurbaşkanlığı Devlet Arşivleri Başkanlığı, Osmanlı Arşivi (BOA)

Bâb-ı Âli Evrak Odası Evrakı (BEO.)3737/280250; 4364/327295.

Dâhiliye Emniyet-i Umûmiye Sicil Kalemi Evrakı (DH. EUM. SCL.) 11/19.

Dâhiliye Nezâreti Emniyet-i Umumiye Asayiş Kalemi (DH. EUM. AYŞ.)16/78;21/87.

Zaptiye Nezâreti Evrakı (ZB.) 314/7; 83/39; 314/4; 122/4.

\section{Kitap ve Makaleler}

"iç̧i Yasağı", Ana Britannica, Cilt: 11, s.461.462.

"içki”, Büyük Larousse Sözlük ve Ansiklopedisi, Cilt: 11, s.5559-5560.

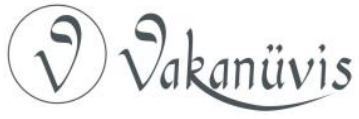


"içki", Dünden Bugüne İstanbul Ansiklopedisi, Tarih Vakfı Yayınları, İstanbul, 1993, Cilt:4, s.132-134.

Akbulut, İlhan, "İslam Hukukunda Suçlar ve Cezalar", Ankara Üniversitesi Hukuk Fakültesi Dergisi, Ankara 2003, Cilt: 52, Sayı:1, s.167-181.

Akbulut, Uğur, "Meyhanelerle Mukaddes Mekânlar Arasında Mesafe Tayini: Sultan II. Abdülhamid Devri İstanbul'undan Örnekler", Karadeniz Araştırmaları, Bahar 2016, Sayı: 49, s.211-224.

Akgündüz, Ahmed, Osmanlı Kanunnâmeleri ve Hukukî Tahlilleri, I. Kitap/ Osmanlı Hukukuna Giriş ve Fatih Devri Kanunnameleri, FEY Vakfı Yayınları, İstanbul, 1990.

Akgündüz, Ahmed, Osmanlı Kanunnâmeleri ve Hukukî Tahlilleri, II. Kitap/ II. Bâyezid Devri Kanunnameleri, FEY Vakfı Yayınları, İstanbul, 1990.

Âşıkpaşazâde Tarihi, Osmanlı Tarihi (1285-1502), (Haz: Necdet Öztürk), Bilge Kültür Sanat, İstanbul, 2013.

Baktır, Mustafa, "İslam'da İçki", İslam Ansiklopedisi, Türkiye Diyanet Vakfı Yayınları, Cilt:21 İstanbul, 2000, s.458-462.

Bayındır, Abdülaziz, "islam Açısından Sarhoş Edici içkiler", İslam Medeniyeti Mecmuası, Cilt:4, Sayı:3, İstanbul, Haziran 1980, s.3-17.

Bozkurt, Fuat, Türk içki Geleneği, Kapı Yayınları, İstanbul, Ağustos 2006.

Bozkurt, Nebi, "içki", İslam Ansiklopedisi, Türkiye Diyanet Vakfı Yayınları, İstanbul, 2000, Cilt 21, s.455-456.

Deal, Roger A., Namus Cinayetleri Sarhoş Kavgaları II. Abdülhamid Döneminde Şiddet, Çeviri: Zeynep Rona, Kitap Yayınevi, İstanbul, Mart 2017

Devellioğlu, Ferit, Osmanlıca-Türkçe Ansiklopedik Lûgat, Aydın Kitabevi, 24.Baskı, Ankara, 2007.

Doğan, Cem, “Osmanlı Men'-i Müskirat Cemiyeti ve Men'-i Müskirat Kanunu" Uluslararası Sosyal Araştırmalar Dergisi, Cilt 6, Sayı 26, Bahar 2013, s.161-181.

Durmuş, illhami, "Türk Kültür Çevresinde Kımız", Milli Folklor Dergisi, 2014, Yıl 26, Sayı 104, s.75-84.

Emiroğlu, Kudret, Gündelik Hayatımızın Tarihi, 3. Baskı, Dost Yayınları, Ankara, 2002

Engin, Vahdettin, Sultan Abdülhamid ve istanbul'u, Simurg Yayınları, İstanbul, 2001.

Erdal, Serkan, Demirci, Hasan, Sivri, Pir Murat, Meşrutiyet'ten Cumhuriyet'e Türkiye'de içki ile Mücadele ve Hilâl-i Ahdar Cemiyeti (19081927), Kitabevi Yayınları, ìstanbul, 2019.

Erdinçli, İhsan, Keyif, Günah ve Suç Arasında Osmanlı'da Meyhaneler ve Müdavimleri, Tarih Vakfı Yurt Yayınları, İstanbul, Haziran 2021.

İnalcık, Halil, Fatih Devri Üzerine Tetkikler ve Vesikalar, Türk Tarih Kurumu Yayınları, Ankara, 2014.

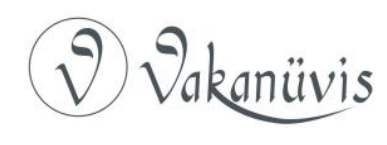


İnalcık, Halil, Has-Bağçede 'Ayş u Tarab: Nedîmler, Şâîler, Mutrîbler, 4. Baskı, İs Bankası Kültür Yayınları, İstanbul, Mart 2018.

İnce, Erdal, "ikinci Meşrutiyet Döneminde Müskirat ve Müskirat Satan Yabancı Esnafa İzin Verilmesi, Tarih ve Günce Atatürk ve Türkiye Cumhuriyeti Tarihi Dergisi, II/5, 2019 Yaz, s.411-430.

Koçu, Reşad Ekrem, Tarihimizde Garip Vakalar, Doğan Kitap, 5. Baskı, İstanbul, 2016.

Köknel, Özcan, Alkol ve Madde Bağımlılığı, Altın Kitaplar Yayınevi, İstanbul, 1998.

Köse, Osman, "XVIII. Yüzyıl Sonlarına Doğru Rus ve Avusturya Savaşları Esnasında Osmanlı Devleti'nde Bir Uygulama: i̇stanbul'da Fuhuş ve içci Yasağı", Turkish Studies Türkoloji Araştırmaları Dergisi, Volume 2/1, Winter 2007, s.104-123.

Naima Mustafa Efendi, Naima Tarihi, I, (Çev. Zuhuri Danışman) Bahar Matbaası, İstanbul, 1967.

Naima Mustafa Efendi, Naima Tarihi, II, (Çev. Zuhuri Danışman) Bahar Matbaası, İstanbul,1968.

Naima Mustafa Efendi, Naima Tarihi, III, (Çev. Zuhuri Danışman) Bahar Matbaası, İstanbul,1968.

Ögel, Bahaeddin, Türk Kültür Tarihine Giriş IV, Kültür Bakanlığı, Ankara, 1991.

Öncü, Fatih, ÖGEL, Kültegin, ÇAKMAK, Duran, "Alkol Kültürü-2: İçki Kültürü Ve Edebiyatta İçki" Bağımılıık Dergisi, Sayı 3, 2002, s.31-36.

Öztürk, Yeter, XIX. Yüzyıl Arşiv Belgelerine Göre Osmanlı Devleti'nde Içki Yasakları, Yayınlanmamış Yüksek Lisans Tezi, Ordu Üniversitesi Sosyal Bilimler Enstitüsü Tarih Anabilim Dalı, Ordu, 2017.

Sevengil, Refik Ahmet, İstanbul Nasıl Eğleniyordu?, Iletişim Yayınları, isstanbul , 1985.

Sülker, Kemal, Osmanlı'dan Günümüze içci ve Toplum, Süreç Yayıncılık, Ankara, 1985.

Şemseddin Sami, Kâmûs-ı Türkî, Çağrı Yayınları, İstanbul, 2012.

Tegin, Ruslan Adil Akai, GÖNÜLALAN Zafer, "Bütün Yönleriyle Doğal Fermente Ürün, Kımı" , Manas Journal of Engineering, 2014, Sayı: 2 (1), s.2334.

Turan, Namık Sinan, "Geleneksel Toplumda Yasağın Cazibesi Osmanlı Toplumunda İçki", Evrensel Kültür, 2012, s.38-42.

Üstün, Çağatay," Eski Bir Türk İ̧̧eceği: Kımız (Koumıss)" Türklük Bilinci Araştırmaları (TÜBAR), 2009-Güz, s.247-255.

Yıldırım, Mustafa, "islam Hukukunda içki iç̧me Suçu ve Cezası", D.E.Ü. Ilahiyat Fakültesi Dergisi, Sayı: XIII-XIV, İzmir 2001, s.31-52.

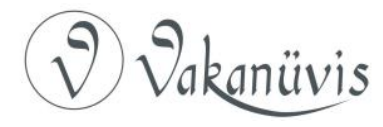

